\title{
Orbitally induced cycles in benthonic foraminiferal morphogroups and trophic structure distribution patterns from the Late Albian "Amadeus Segment" (Central Italy)
}

\author{
RODOLFO COCCIONI \\ Istituto di Geologia dell'Università \\ Via S. Chiara, 27 \\ I-61029 Urbino (Italy)
}

\author{
SIMONE GALEOTTI \\ Istituto di Geologia dell'Università \\ Via S. Chiara, 27 \\ I-61029 Urbino (Italy)
}

\begin{abstract}
A detailed analysis was made of benthonic foraminiferal distribution patterns and morphogroups in the late Albian "Amadeus Segment" of the Aptian-Albian organic-rich Scisti a Fucoidi Formation outcropping over a widespread area of the Umbria-Marche region, Central Italy. Rhythmic changes in the trophic structures and composition of benthonic foraminiferal assemblages suggest cyclical fluctuations of the sea floor environment which appear to be orbitally induced. Benthonic foraminiferal assemblages varied significantly through the section and appear to contain a strong paleoecological signal. Fluctuations in both bottom water oxygenation and the surface primary productivity as a result of the orbital forcing are interpreted to have been the primary controls on benthonic foraminiferal distribution patterns. J. Micropalaeontol. 12 (2): 227-239, December 1993.
\end{abstract}

\section{INTRODUCTION}

Foraminifera have been extensively used for paleoenvironmental interpretation, and the use of various morphological groups in benthonic foraminiferal assemblages is not new. This approach has been used, especially in the Cretaceous, to study the organic rich strata which were a global component of this period in a variety of lithologies and paleoenvironments. Several studies (Jones \& Charnock, 1985; Bernhard, 1986; Corliss \& Chen, 1988; Coccioni, 1990a and b; Koutsoukos \& Hart, 1990; Coccioni \& Galeotti, 1991; Kaiho, 1991, among others) have shown the utility of this method and its potential in detecting the paleoceanographic conditions in which the hypoxic/anoxic events took place. Moreover, the influence of orbital forcing on benthonic foraminiferal assemblage pattern distribution has been recently recognized by Cottle (1989), Leary et al. (1989), and Coccioni \& Galeotti (1991).

The present study aims to document the benthonic foraminiferal distribution patterns from the Late Albian "Amadeus Segment" (Coccioni \& Galeotti, 1991) of the Fiume Bosso section (Fig. 1), using a morphological approach.

\section{THE "AMADEUS SEGMENT" (I)}

This 193-cm thick stratigraphic interval belongs to the "Whitish Marly Limestone Member" of the Scisti a Fucoidi Formation (Coccioni et al., 1987, 1989 and 1990b) (Fig. 2) which, according to several authors (Fischer et al.,1985; Fischer \& Herbert, 1988; Premoli Silva et al., 1989b; Coccioni et al., 1990b; Erba, 1992; Coccioni et al., 1990 b, among

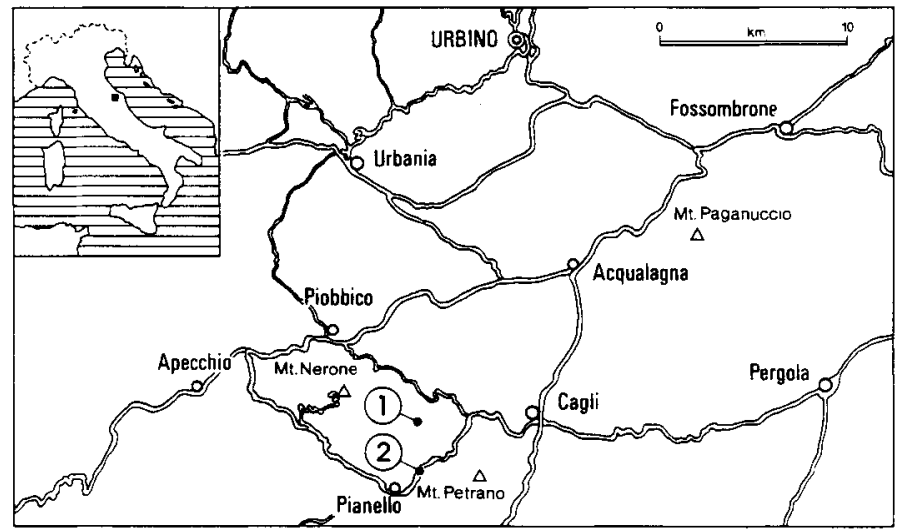

Fig. 1 Location of the Poggio le Guaine (1) and Fiume Bosso (2) sections which following Coccioni et al. (1990a and b) are the reference sections for the Scisti a Fucoidi Formation in the Umbria-Marche Apennines Basin. The sections outcrop in Geological Map of Italy, F. 290 "Cagli", 1:50.000.

others), was deposited at a mean sedimentation rate of $5 \mathrm{~m} / \mathrm{Ma}$. The Amadeus Segment which corresponds lithoand biostratigraphically to the ca. $400 \mathrm{ka}$-Segment 1 of Premoli Silva et al. (1989a and b) consists of a rhythmic alternation of whitish marls and calcareous marls, and black shales characterized by a Corg content $>1 \%$ (group 2 of Premoli Silva et al., 1989a); some radiolarian rich layers occur (Figs 3-4). Rhythmic Cretaceous sequences (e.g. the Scisti a Fucoidi) of the Umbria-Marche Basin of the central Italy were studied by several authors (de Boer, 1982; Schwarzacher \& Fischer, 1982; de Boer \& Wonders, 1984;

(1) The "Amadeus Segment" was named by Coccioni \& Galeotti (1991) to celebrate the second centennial anniversary of the death of Wolfgang Amadeus Mozart (1756-1791). On the other hand isn't the rhythmic alternation of whitish carbonate-rich layers and black shale reminiscent of a piano keyboard? 

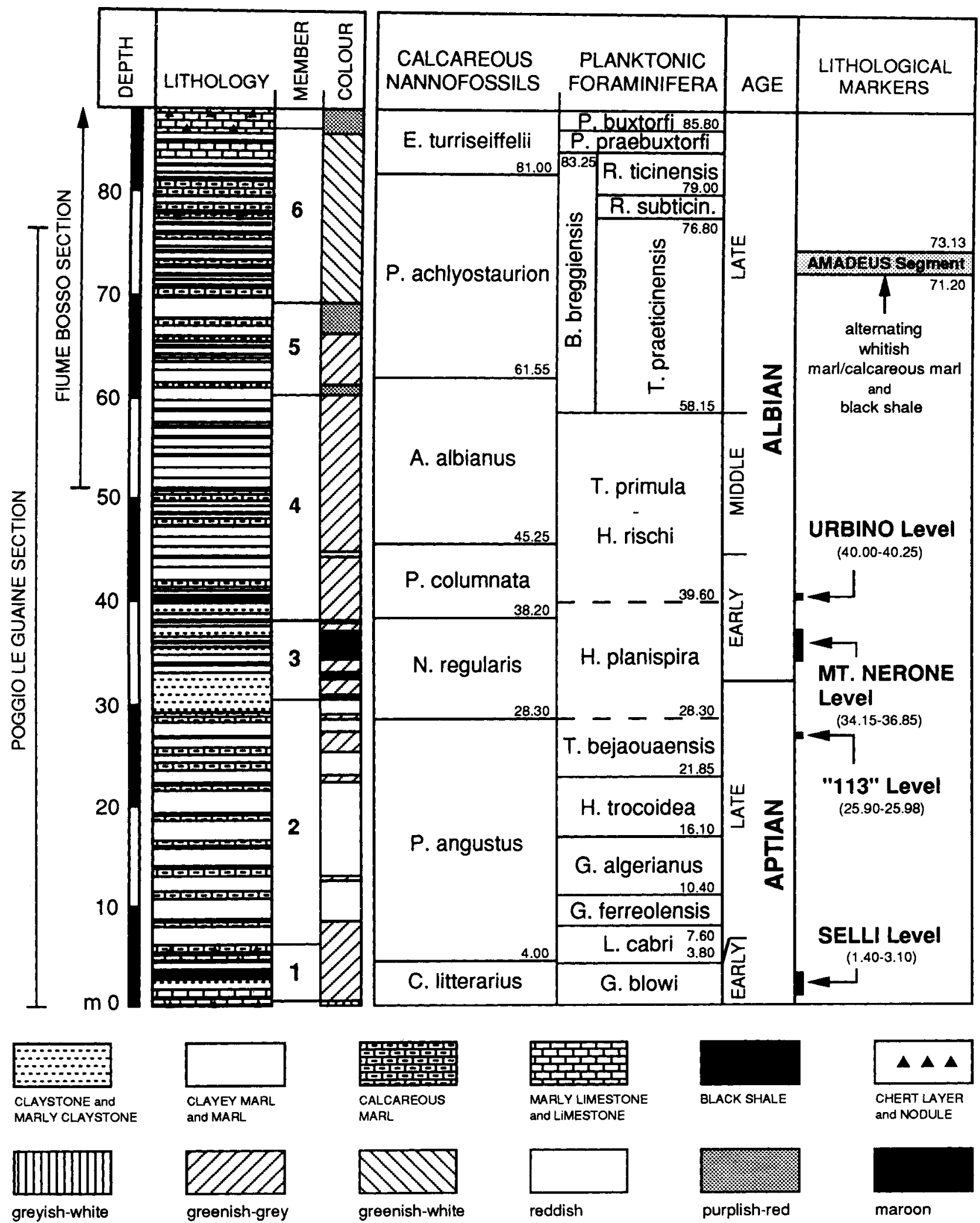

greyish-white
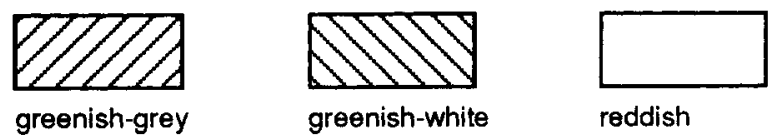

reddish
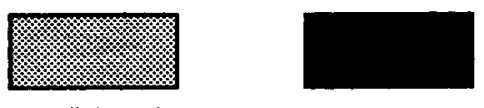

Fig. 2 Lithostratigraphy and biostratigraphy of the Poggio le Guaine-Fiume Bosso composite sequence (after Coccioni et al., 1990a and b, modified). Numbers indicate metres above the base. The right column indicates the positions of the Amadeus Segment and of four distinctive global and regional marker black-shales layers. 

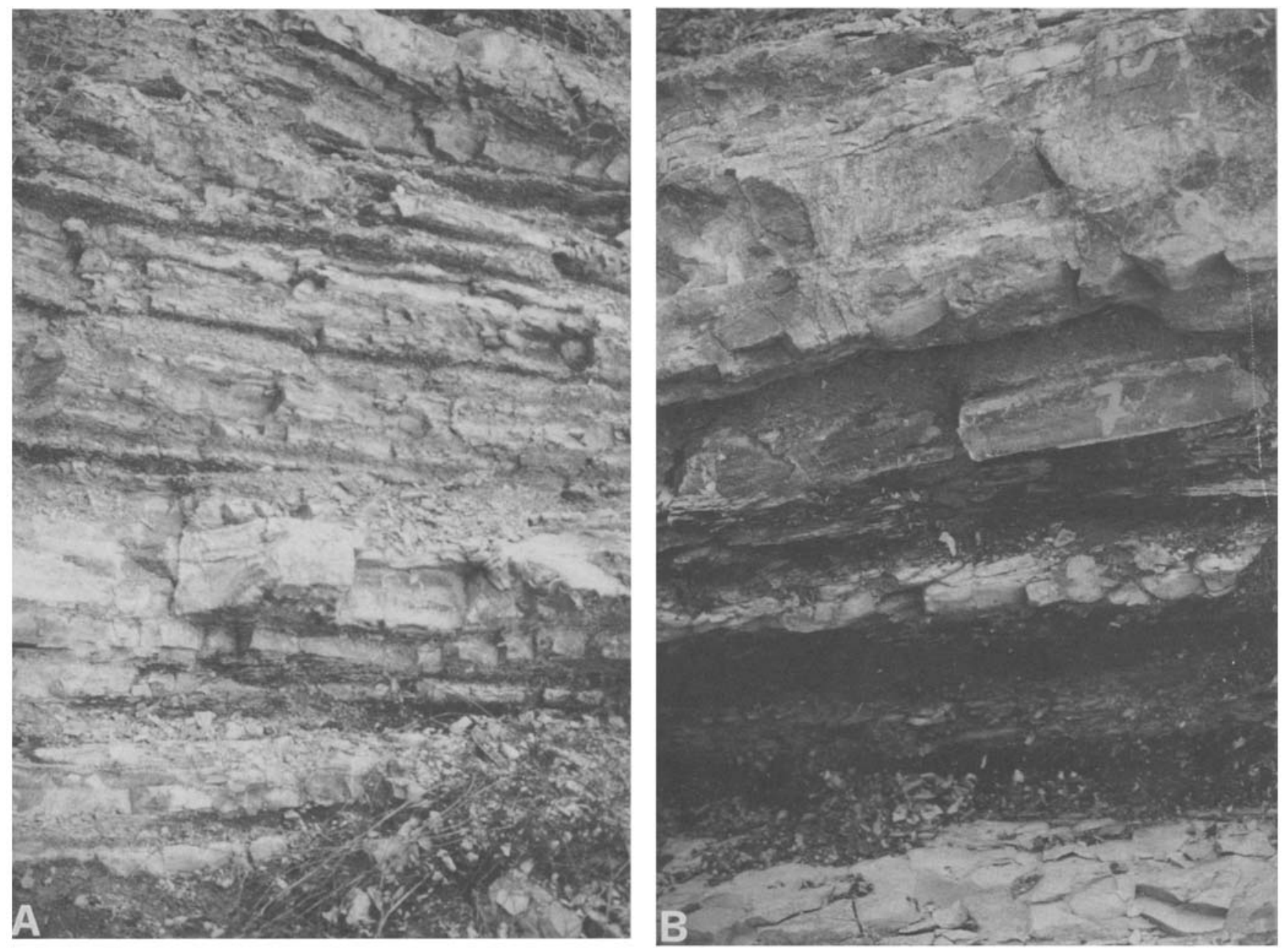

Fig. 3 A: The Amadeus Segment in outcrop. B: Detail of the previous photograph showing the rhythmic alternation of whitish marls and calcareous marls, and black shales.

Fischer \& Schwarzacher, 1984; Fischer et al., 1985; Herbert \& Fischer, 1986; Herbert et al., 1986; Herbert, 1987 and 1992; Fischer \& Herbert, 1988; Fischer et al., 1991; among others) who demonstrated that the bedding rhythms reflect the Earth's orbital variations. According to Herbert \& Fischer (1986), Herbert (1987), and Fischer \& Herbert (1988) the marl-limestone bedding couplets of the stratigraphic interval including the Amadeus Segment record the precession cycle (19-23 ka) and a grouping of these couplets into bundles records the short cycle of eccentricity (95-125 $\mathrm{ka}$. According to these authors these cycles result from changes in carbonate productivity and sea-floor stagnation. Even changes in abundance of planktonic foraminifera and trace fossils distributions were shown to be orbitally controlled (Premoli Silva et al., 1989a and c; Premoli Silva \& Erba, 1991).

\section{MATERIAL AND METHODS}

The Amadeus Segment was sampled bed by bed (at approximately $5-\mathrm{cm}$ intervals) from a deep trench to eliminate surface contamination. The samples were marked

as AMS 1 to AMS 38 from bottom to top. The $\mathrm{CaCO}_{3}$ content of each sample was estimated volumetrically. Sample preparation for foraminiferal study involved: crushing of $150 \mathrm{gr}$ of sample; disaggregation by diluted hydrogen peroxide; washing through a $32 \mu \mathrm{m}$ sieve; and drying. All the benthonic foraminifera were picked from the three coarser fractions ( $>420 \mu \mathrm{m}, 420-250 \mu \mathrm{m}, 250-125 \mu \mathrm{m}$ ) into numbered slides for quantitative analysis. The composition of the remaining fraction $(<125 \mu \mathrm{m})$ was only noted, but in no cases did it contain species not recorded from the other fractions. The classification followed is based on Loeblich \& Tappan (1988). Plates 1 and 2 illustrate all identified taxa.

The quantitative analysis was carried out by studying the variations in abundance of the species within the assemblages. On the basis of their shape, chamber arrangement, and inferred mode of life, the recognized species were grouped into 10 morphogroups (see Table 1); then, the variations in relative abundance of these groups within the assemblages were observed. To obtain information on the trophic structure variations a number of 


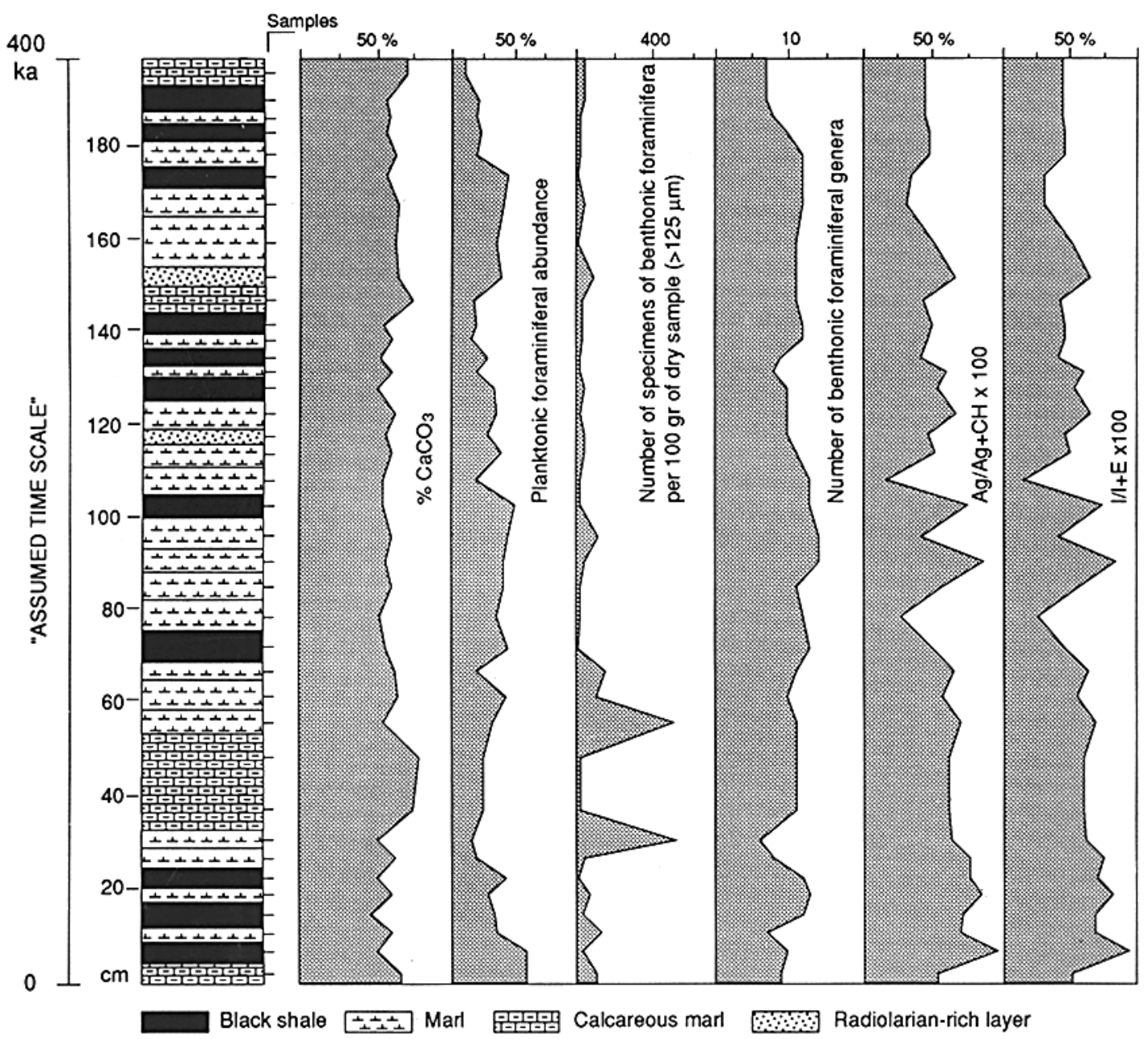

Fig. 4 Generalized lithological log of the Amadeus segment and variations of some peculiar data. Abbreviations as follows: $\mathrm{Ag}=$ Agglutinated benthonic foraminifera, $\mathrm{CH}=$ Calcareous-hyaline benthonic foraminifera, $\mathrm{I}=$ Infaunal forms, $\mathrm{E}=\mathrm{Ep}$ ifaunal forms .

indices were calculated including: the number of specimens per $100 \mathrm{~g}$ of dried sample; the number of genera per sample; the infaunal (I)/epifaunal (E) forms ratio calculated as $\mathrm{I} / \mathrm{I}+\mathrm{E} \times 100$; and the agglutinating $(\mathrm{Ag}) /$ calcareous hyaline (CH) forms ratio calculated as $\mathrm{Ag} / \mathrm{Ag}+\mathrm{CH} \times 100$. The absolute abundance of planktonic foraminifera was estimated by counting on a graduated screen and comparing obtained values with those from grain-size diagrams (Baccelle \& Bosellini, 1965).

Finally, to detect periodicity in the foraminiferal data, a fourier function analysis was applied to the abundance records of each species, genus, and morphogroup. This analysis was carried out by using the Strata Base 6.1 program (Ripepe, 1988). The type of sampling might have affected the result of the spectral analysis since it did not take into account the possible variations within a single layer and because it was too wide. However, detailed study of samples taken in several sites along a single layer showed consistency of benthonic foraminiferal assemblages. Furthermore, only spectral analyses that showed cyclicity clearly enough to be retained as primary were considered valid.

\section{RESULTS}

The $\mathrm{CaCO}_{3}$ content of the Amadeus Segment ranges from 50 to $75 \%$ (Fig. 4 ), with minima of $50-55 \%$ in the blackshales. Planktonic foraminifera are more abundant in samples with low carbonate content with greatest abundance in the marly layers, whereas they decrease in abundance in samples rich in carbonate (Fig. 4).

The benthonic foraminiferal assemblages of the Amadeus Segment are composed of calcareous hyaline and both calcareous and silicified-walled agglutinating forms. Preservation is moderate to good. Forty-two species were identified belonging to twenty-two genera among which Gyroidinoides, Arenobulimina, Dorothia, and Clavulinoides predominate.

The benthonic foraminiferal assemblages change with lithology and three distinct associations can be recognized (Table 3):

(a) Marl Association (MA):

(i) High abundance;

(ii) High diversity;

(iii) Low dominance 


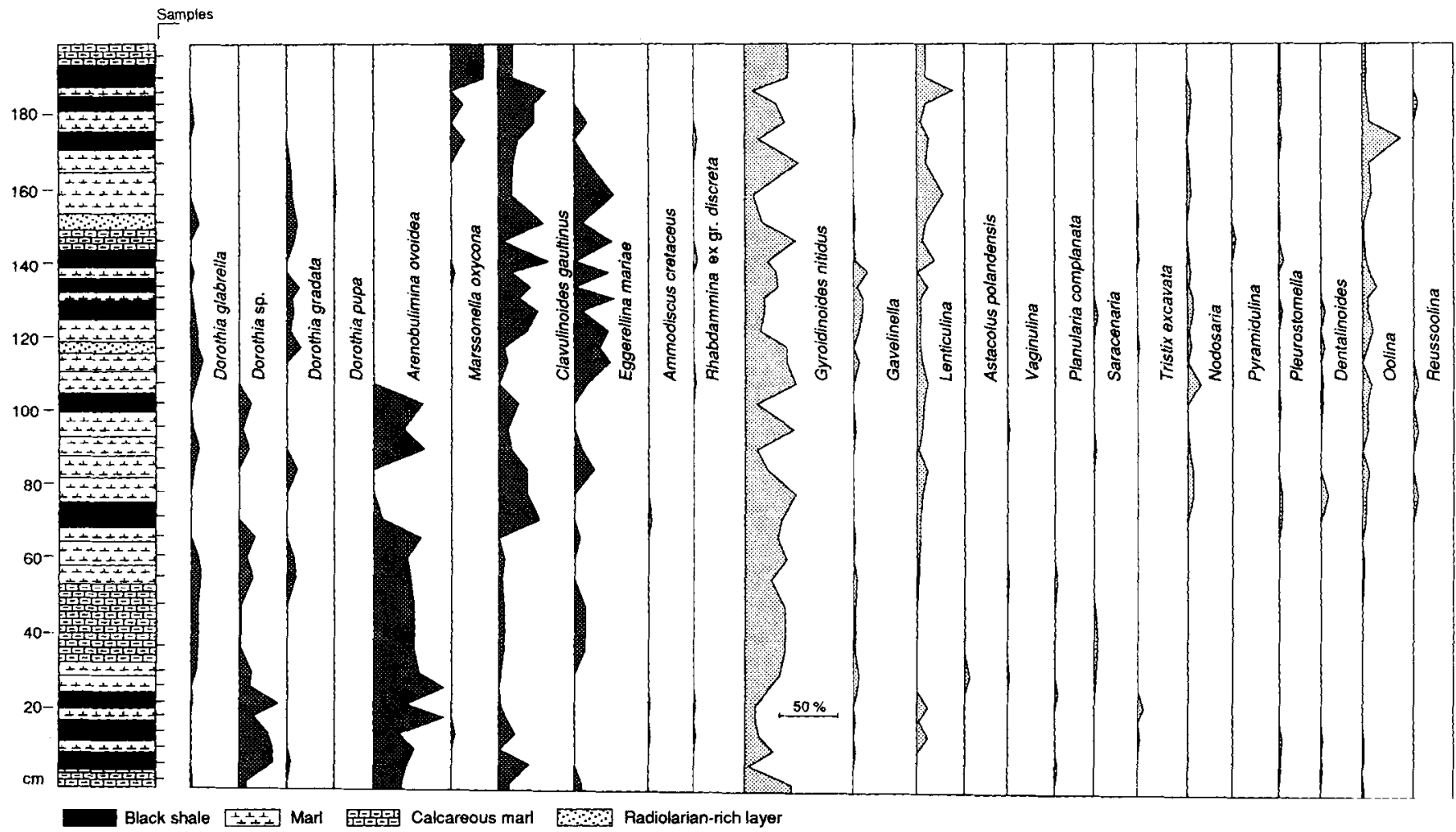

Fig. 5 Generalized lithological log of the Amadeus Segment and relative abundance percentages of benthonic foraminiferal genera and species. Dark stippled=infaunal forms, light stippled=epifaunal forms. Assumed Time Scale as in fig. 4.

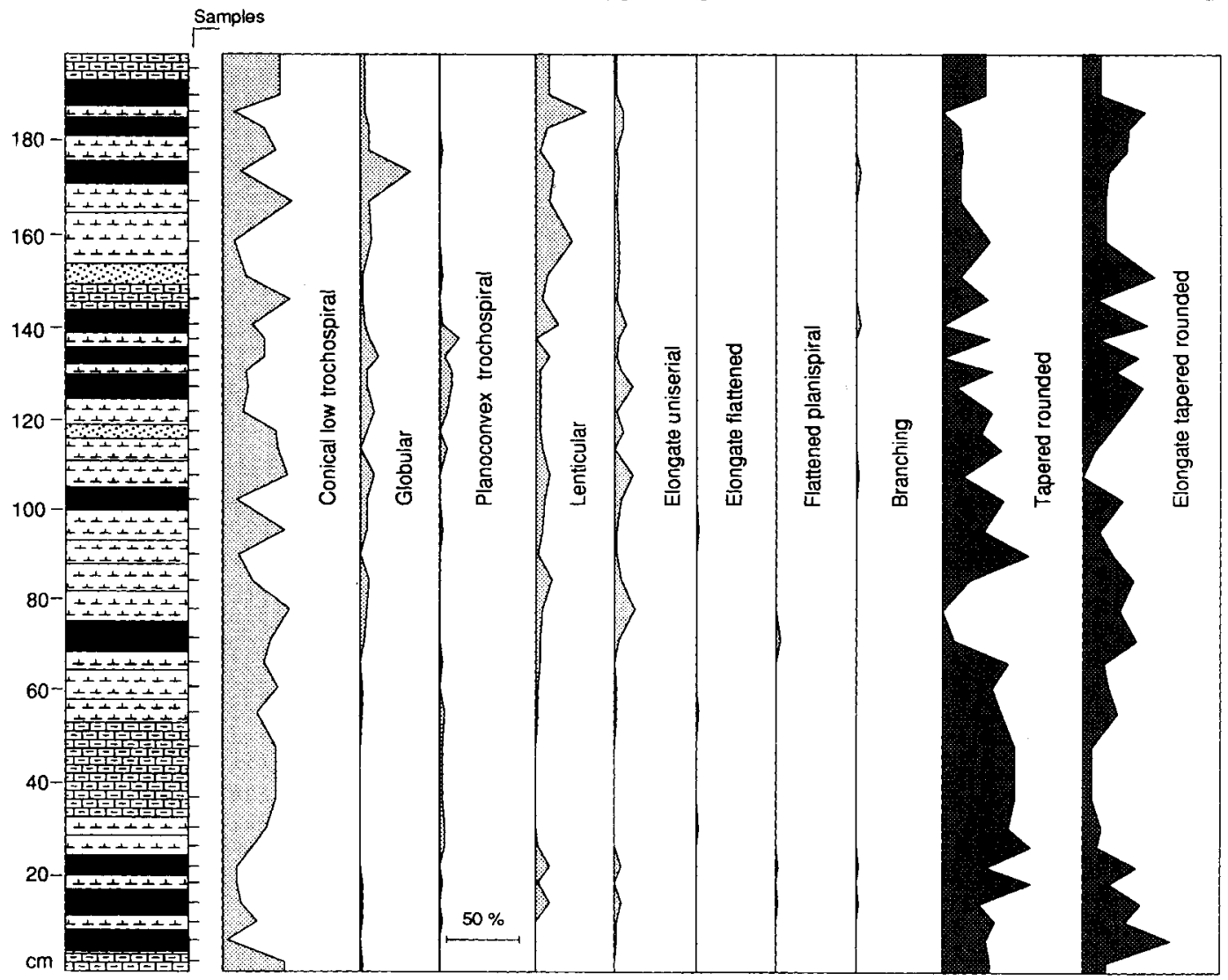

Fig. 6 Generalized lithological log of the Amadeus Segment and relative abundance percentages of benthonic foraminiferal morphogroups. Light stippled=epifaunal forms, dark stippled=infaunal forms. Assumed Time Scale as in fig. 4. 
(iv) Large size of the specimens $(>250 \mu \mathrm{m})$;

(v) Predominance of low surface to volume ratio morphotype;

(b) Calcareous Marl Association (CMA):

(i) Low abundance;

(ii) Variable diversity;

(iii) High dominance;

(iv) Small size of the specimens $(<250 \mu \mathrm{m})$;

(c) Black-Shale Association (BSA):

(i) Low abundance;

(ii) Low diversity;

(iii) High dominance;

(iv) Small size of the specimens $(<250 \mu \mathrm{m})$;

(v) Predominance of high surface to volume ratio morphotypes.

The distribution of many species, genera, and morphogroups through the Amadeus Segment appears to be cyclical (Figs. 5 and 6). However, some of them (e.g. Marssonella oxycona, Pleurostomella, and branching morphotypes) exhibit such a discontinuous distribution that it would be very difficult to carry out a significant evaluation. On the basis of an assumption of uniform sedimentation rate, the spectral analyses support the hypothesis that, in some cases, the cyclicities appear to be astronomically driven (Fig. 7). In addition, since other workers (Herbert \& Fischer, 1986; Herbert, 1987; Fischer \& Herbert, 1988; Premoli Silva et al., 1989a and b; Fischer et al., 1991) have already provided strong evidence of Milankovitch Cyclity influencing sedimentation in this sequence, then it is reasonable to interpret the benthonic foraminiferal patterns in this context.

The following can be recognized: (i) the precession cycle (19-23 ka) followed by Gyroidinoides nitidus, Clavulinoides gaultinus, and tapered rounded elongate, tapered rounded, lenticular, and conical low trochospiral morphogroups, (ii) the short eccentricity cycle $(95-123 \mathrm{ka})$ followed by Clavulinoides gaultinus, Lenticulina, and elongate tapered rounded, tapered rounded, and lenticular morphogroups (Table 2). Consequently, variations in the trophic structure, assume cyclical aspects. In fact, the paleocommunities mainly consisting of infaunal forms and those mainly consisting of epifaunal forms, alternate with a periodicity correlatable to the obliquity (42 ka) and precession (19-23 ka) cycles (Fig. 7), whereas the benthonic foraminiferal abundance variations record the obliquity cycle. Inverse relationships can be observed between Gavelinella and Lenticulina, between G. nitidus and C. gaultinus, and between elongate tapered rounded and tapered rounded morphogroups.

\section{DISCUSSION}

Several authors (Corliss, 1985; Bernhard, 1986; Corliss \& Chen, 1988; Coccioni, 1990; a and b; Bartolini et al., 1990; Koutsoukos \& Hart, 1990; Coccioni \& Galeotti, 1991; Kaiho, 1991, among others) have shown that test size and predominant morphologies of benthonic foraminifera from hypoxic/anoxic deposits differ from those of oxic deposits. Based on these works the benthonic foraminiferal distribution patterns in the Amadeus Segment can be largely explained in terms of oxygen content variations. Both the composition and the abundance of the benthonic foraminiferal assemblages are different in the different lithotypes. The BSA composition suggests a high degree of oxygen depletion on the bottom water. In contrast, both the MA and the CMA compositions are indicative of well oxygenated bottom water. The MA assemblage displays highest abundance of benthonic foraminifera in the fraction greater than $125 \mu \mathrm{m}$. This measure of the benthonic foraminiferal assemblages (benthonic foraminiferal flux) has been shown to be directly linked to organic flux rates (Herguera \& Berger, 1991) suggesting fluctuation in primary productivity. The low abundance in the CMA is, probably, a reflection of rapid sedimentation, which may dilute the benthos.

On the basis of the distribution of species, genera and morphogroups in the different lithotypes which are assumed to reflect different oxygenation conditions, we have tried to identify aerobic, intermediate, and anaerobic forms (Table 3). According to some authors (Bernhard, 1986; Coccioni, 1990a and b; Kaiho, 1991) infaunal anaerobic forms have higher surface area-to-volume ratios than aerobic ones. Leutenegger \& Hansen (1979) suggested that high surface area-to-volume ratios and high porosity tests could provide a greater area for mitochondrial oxygen uptake. Moreover, we suggest that tapered and elongate morphologies could facilitate movement towards the watersediment interface where the quantity of dissolved oxygen is greater.

The infaunal assemblages are devoid of intermediate forms (Table 3 ). This suggests, the infaunal forms were highly sensitive to dissolved oxygen content changes. Conversely, the epifaunal assemblages are almost entirely represented by intermediate forms, suggesting less sensitivity of these assemblages to oxygen content variations.

The aerobic assemblages include a good percentage of Pleurostomella specimens which, on the contrary, was suggested as an anaerobic index by Bernhard (1986) and Kaiho (1991). Moreover, other forms considered aerobic by these authors (e.g., planoconvex, lenticular, globular/sphaerical morphotypes) or anaerobic (e.g., Nodosaria and Dentalinoides) are here considered intermediate indices of dissolved oxygen content.

The infaunal anaerobic forms from the Amadeus Segment have a high surface area to volume ratio, while epifaunal forms with a very high surface area to volume ratio represent intermediate or even aerobic indices. This implies that, in certain conditions, a particular morphology can be adaptive for an infaunal strategy but not for an epifaunal strategy. In conditions where oxygenation is low, for example, an infaunal species with a cylindrical and elongate morphology may have had an advantage because it could move more easily towards the water-sediment interface 


\begin{tabular}{|c|c|c|}
\hline MORPHOGROUP & GENUS/SPECIES & TROPHIC STRATEGY \\
\hline Lenticular & $\begin{array}{l}\text { Lenticulina } \\
\text { Saracenaria } \\
\text { Astacolus } \\
\text { Planularia }\end{array}$ & \multirow{6}{*}{$\begin{array}{l}\text { Epifaunal to shallow infaunal } \\
\text { deposit feeders }\end{array}$} \\
\hline Elongate flattened & Vaginulina & \\
\hline Globular & $\begin{array}{l}\text { Reussolina } \\
\text { Oolina }\end{array}$ & \\
\hline Elongate uniserial & $\begin{array}{l}\text { Dentalinoides } \\
\text { Nodosaria } \\
\text { Pyramidulina } \\
\text { Tristix } \\
\text { Pleurostomella } \\
\text { Pseudonodosaria }\end{array}$ & \\
\hline Conical low trochospiral & Gyroidinoides & \\
\hline Flattened planispiral & Ammodiscus & \\
\hline Branching & Rhabdammina & $\begin{array}{l}\text { Elevated, erect suspension } \\
\text { feeder }\end{array}$ \\
\hline Planoconvex trochospiral & Gavelinella & $\begin{array}{l}\text { Epifaunal living on } \\
\text { elevated substrate? }\end{array}$ \\
\hline Elongate tapered rounded & $\begin{array}{l}\text { D. gradata } \\
\text { D. sp. } \\
\text { C. gaultinus }\end{array}$ & \multirow[b]{2}{*}{ Infaunal deposit feeders } \\
\hline Tapered rounded & $\begin{array}{l}\text { A. ovoidea } \\
\text { D. glabrella } \\
\text { M. oxycona } \\
\text { E. mariae } \\
\text { D. pupa }\end{array}$ & \\
\hline
\end{tabular}

Table 1 Benthonic foraminiferal morphogroups and trophic strategies in the Amadeus Segment. Genera and species are arranged in taxonomic order.

\begin{tabular}{|c|l|l|l|}
\hline $\begin{array}{c}\text { AMADEUS } \\
\text { SEGMENT }\end{array}$ & \multicolumn{1}{|c|}{$\begin{array}{c}\text { Short Eccentricity Cycle } \\
(95-127 \mathrm{ka})\end{array}$} & $\begin{array}{c}\text { Obliquity Cycle } \\
\text { (ca. 40 ka) }\end{array}$ & $\begin{array}{c}\text { Precession Cycie } \\
(19-23 \mathrm{ka})\end{array}$ \\
\hline Genera/Species & $\begin{array}{l}\text { D. glabrella } \\
\text { Lenticulina } \\
\text { C. gaultinus }\end{array}$ & $\begin{array}{l}\text { D. glabrella } \\
\text { Lenticulina }\end{array}$ & $\begin{array}{l}\text { Lenticulina } \\
\text { C. gaultinus } \\
\text { G. nitidus }\end{array}$ \\
\hline Morphogroups & $\begin{array}{l}\text { Lenticular } \\
\text { Tapered rounded } \\
\text { Tapered elongate rounded }\end{array}$ & Lenticular & Lenticular \\
\hline Trophic structure & & $\begin{array}{l}\text { I/l+E X } 100 \\
\text { number of specimens }\end{array}$ & $1 / 1+E \times 100$ \\
\hline
\end{tabular}

Aerobic

\begin{tabular}{|c|c|c|c|}
\hline $\begin{array}{l}\text { Infaunal } \\
\text { forms }\end{array}$ & $\begin{array}{l}\text { A. ovoidea } \\
\text { D. gradata } \\
\text { E. mariae }\end{array}$ & - & $\begin{array}{l}\text { D. gradata } \\
\text { D. sp. } \\
\text { C. gaultinus }\end{array}$ \\
\hline $\begin{array}{l}\text { Epifaunal } \\
\text { forms }\end{array}$ & $\begin{array}{l}\text { G. flandrini } \\
\text { Pleurostomella }\end{array}$ & $\begin{array}{l}\text { Nodosaria } \\
\text { Saracenaria } \\
\text { Lenticulina } \\
\text { Oolina } \\
\text { G. nitidus }\end{array}$ & $\begin{array}{l}\text { R. ex gr. discreta } \\
\text { A. cretaceus }\end{array}$ \\
\hline $\begin{array}{l}\text { Infaunal } \\
\text { forms }\end{array}$ & Tapered elongate & - & Tapered rounded elongated \\
\hline $\begin{array}{l}\text { Epifaunal } \\
\text { forms }\end{array}$ & Planoconvex trochospiral & $\begin{array}{l}\text { Conical low trochospiral } \\
\text { Elongate uniserial } \\
\text { Globular } \\
\text { Lenticular }\end{array}$ & $\begin{array}{l}\text { Branching } \\
\text { Flattened planispiral }\end{array}$ \\
\hline
\end{tabular}

Table 2 Benthonic foraminifera and cyclicity in the Amadeus Segment. Genera and species are arranged in taxonomic order.
Table 3 Aerobic, intermediate, and anaerobic forms in the Amadeus Segment based on distribution in different lithologies. A=genera and species, $\mathrm{B}=$ morphogroups. 
Number of specimens of benthonic foraminifera (> $125 \mu \mathrm{m}$ ) per $100 \mathrm{~g}$ of dry sample
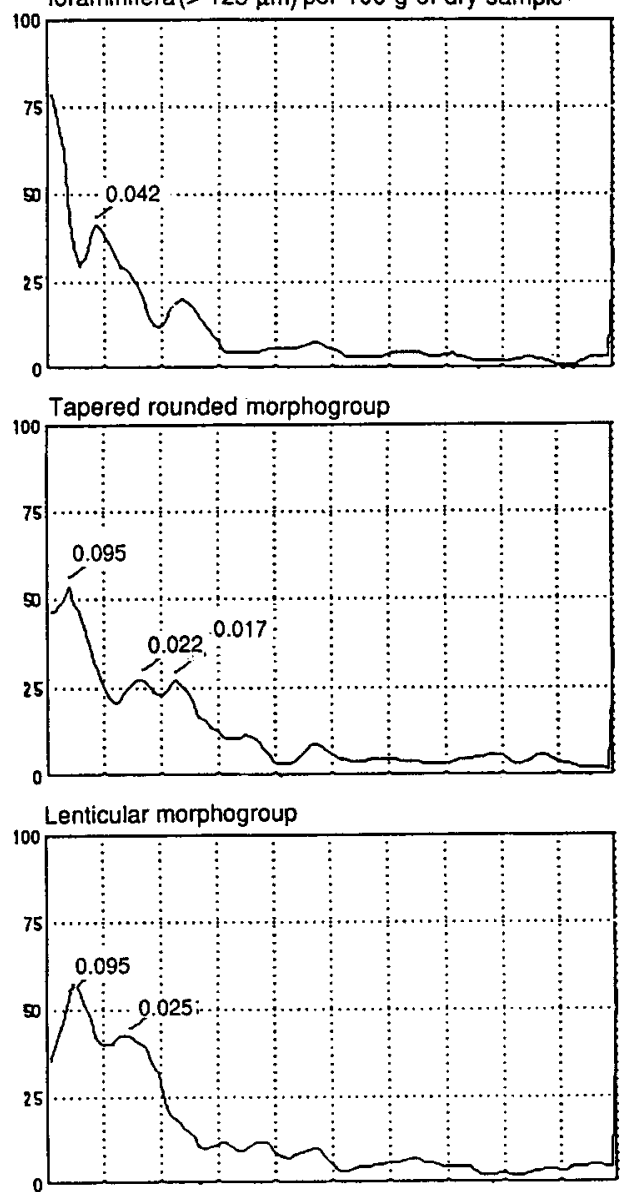

G. nitidus/Conical low trochospiral morphogroup

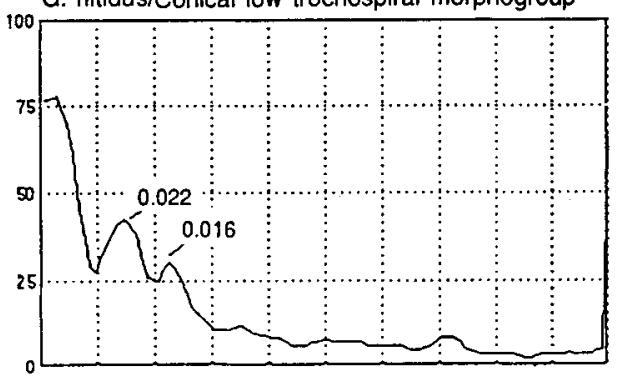

$\mathrm{I} / \mathrm{I}+\mathrm{E} \times 100$

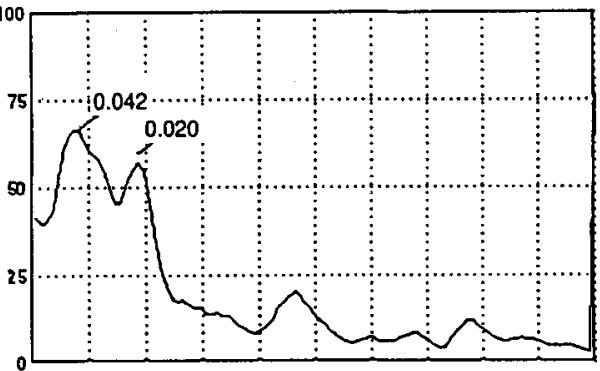

Elongate tapered rounded morphogroup

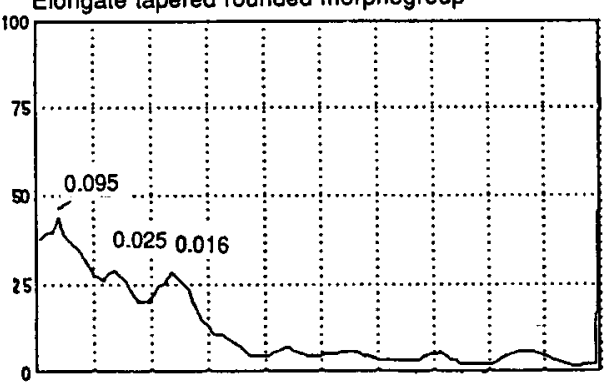

C. gaultinus
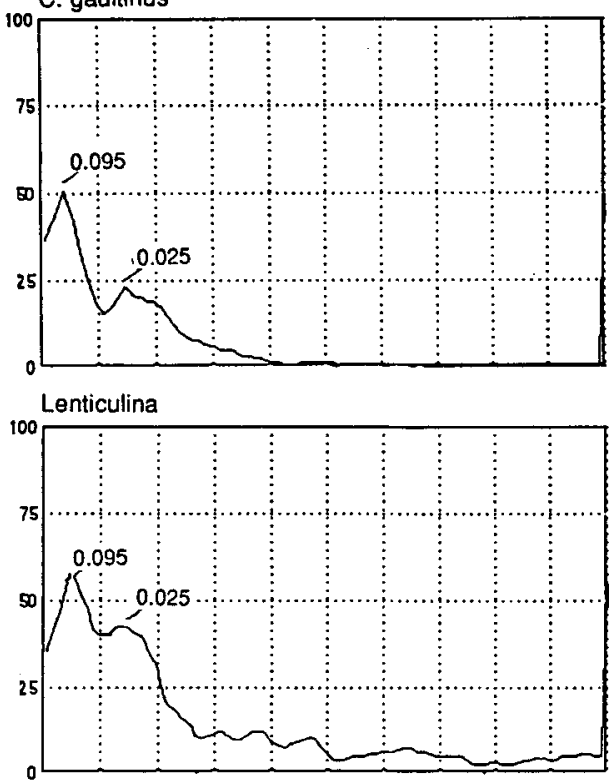

Fig. 7 Spectral analyses of the benthonic foraminiferal assemblages distribution throughout the Amadeus Segment. For each spectrum, the vertical axis represents power, the horizontal axis is harmonic number. Particularly strong peaks are labelled with their periodicity, in Ma.

\section{Explanation of Plate 1}

Fig. 1. Gyroidinoides nitidus (Reuss), sample AMS 8, x58. Fig. 2. Lenticulina sp., sample AMS 1, x70. Fig. 3. Lenticulina gaultina (Berthelin), sample AMS 8, x53. Fig. 4. Lenticulina ovalis (Reuss), sample AMS 8, x53. Fig. 5. Lenticulina cf. acuta (Reuss), sample AMS 11, x35. Fig. 6. Astacolus polandensis (Trujillo), sample AMS 8, x53. Fig. 7. Vaginulina sp., sample AMS 18, x53. Fig. 8. Planularia complanata (Reuss), sample AMS 2, x106. Fig. 9. Vaginulina kochii Roemer, sample AMS 8, x94. Fig. 10. Saracenaria sp., sample AMS 8, x53. Fig. 11. Saracenaria bullata (Berthelin), sample AMS 30, x35. Fig. 12. Tristix excavata (Reuss), sample AMS 8, x53. Fig. 13. Nodosaria humilis Roemer, sample AMS 2, x35. Fig. 14. Pseudonodosaria sp., sample AMS 16, x53. Fig. 15. Pyramidulina obscura (Reuss), sample AMS 2, x35. Fig. 16. Pyramidulina paupercola (Reuss), sample AMS 2, x35. Fig. 17. Nodosaria limbata d'Orbigny, sample AMS 30 , x53. Fig. 18. Nodosaria sp. 1, sample AMS 26, x70. Fig. 19. Nodosaria sp. 2, sample AMS 1, x70. Fig. 20. Nodosaria sp. 3 , sample AMS 2, x70. 


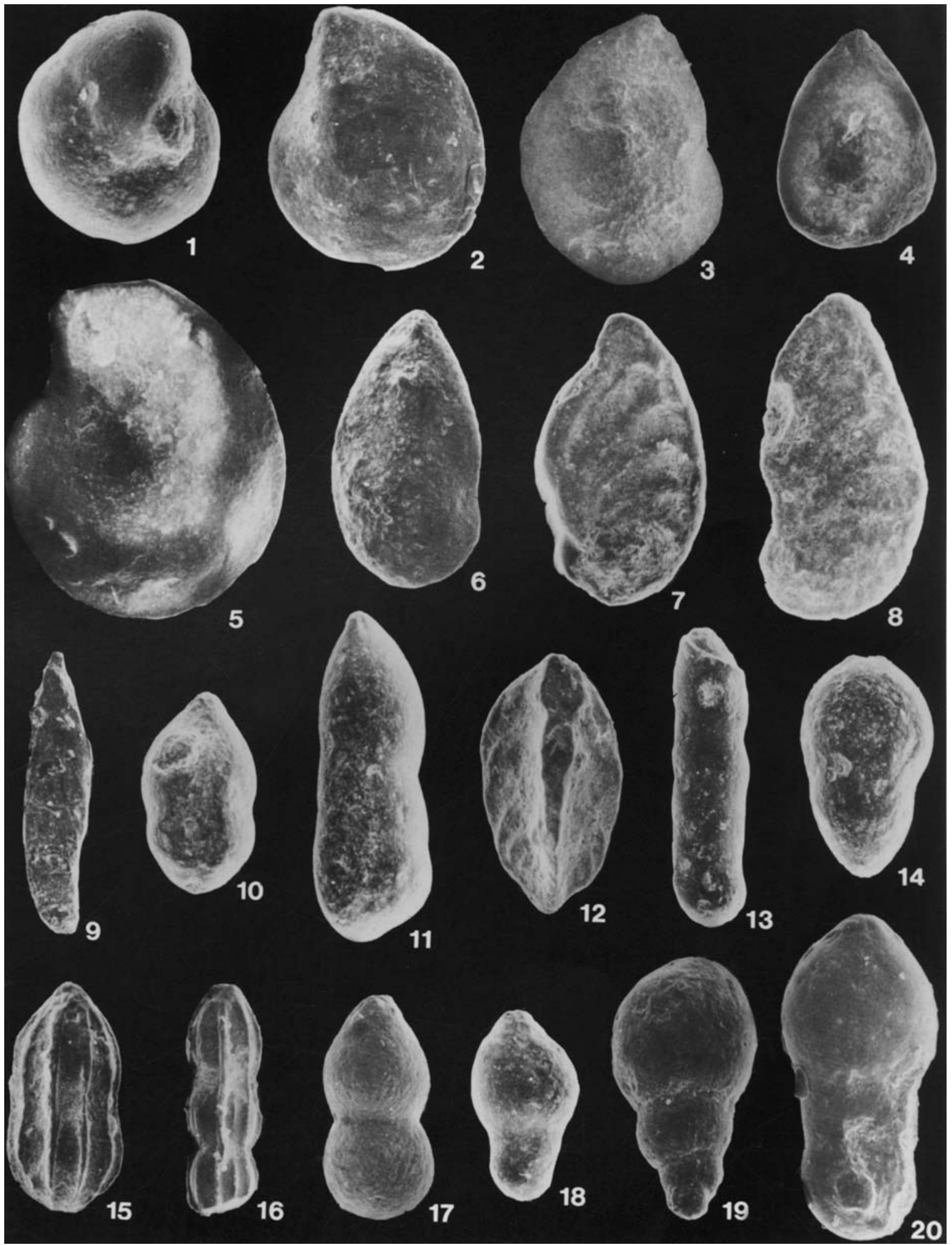


where there is a greater quantity of dissolved oxygen. In the same oxygenation conditions an epifaunal species with the same morphology might have been at a disadvantage because it would tend to sink into the substrate where the dissolved oxygen content is lower. Furthermore, it is possible that similar morphotypes can be characterized by a different feeding strategy. In this case the distribution of the morphogroups would be influenced not only by the dissolved oxygen content but also by the availability of nutrients on the sea floor.

Most of morphological studies on benthonic foraminiferal assemblages in dysaerobic environments have been carried out on sediments deposited under conditions of high epipelagic production. The high primary productivity levels contribute to high nutrient fluxes in the form of particulate organic material inducing oxygen deficiency in bottom waters. Deposited organic matter and bacteria are the primary trophic resource for the microbenthos thriving under such conditions. Contrary to this model, the black shale layers from the Amadeus Segment represent conditions of moderate to low fertility (Premoli Silva et al., 1989a; Erba, 1988 and 1992); this helps to explain the different behaviour of the epifaunal assemblages from the Amadeus segment to those studied by Bernhard (1986) and Kaiho (1991) (see above).

The cyclical assemblage changes recognized in the Amadeus Segment are, probably, a result of cyclical changes in both oxygen content and primary productivity induced by orbital forcing. In fact variations of these two parameters cause considerable changes in the trophic structure of the bottom environment and so in the benthonic communities (Jones \& Charnock, 1985; Bernhard, 1986; Coccioni, 1990b; Koutsoukos \& Hart, 1990; Premoli Silva \& Erba, 1991, among others).

The influence of orbital forcing on benthonic foraminiferal assemblage pattern distribution has been reported previously from the Cenomanian and Turonian of southern England (Leary et al., 1989; Cottle, 1989) and from the Late Albian of Central Italy (Coccioni \& Galeotti, 1991). Leary et al. (1989) showed that changes in the abundance of Lenticulina and Gavelinella were related to changes in amount of introduced carbonate sediment as a consequence of the precessional forcing of the climate. Detailed sampling of two sections of Turonian-aged Chalk from south-east England for foraminifera has revealed that cyclical abundance changes of Gyroidinoides nitidus and Gavelinella emscheriana were mediated by orbitally induced climatic cycles (Cottle, 1989). In particular, changes in abundance of G. nitidus were driven by the obliquity cycle. Instead, in the Amadeus Segment the cyclical changes in abundance of this species are correlatable to the precessional cycle. Evidently, a single species may show a different sensitivity to orbital forcing through time (probably under different climatic regimes) or at different paleolatitudes.

\section{CONCLUSIONS}

Abundance, taxonomic composition, morphology, and test size of benthonic foraminifera fluctuate greatly from layer to layer throughout the Amadeus Segment reflecting dynamic fluctuations of the sea floor environment.

With respect to lithology, three peculiar associations (MA, CMA, and BSA) have been identified which we suggest to be related to different degrees of primary productivity and oxygenation of the bottom water. This paper provides evidence that these changes are the result of orbitally induced productivity and redox cycles.

The influence of orbital forcing has been recognized in the distribution of some species, genera and morphogroups. Moreover, the orbital forcing drives cyclic changes in the trophic strategies. Our data demonstrate that a single species may show different sensitivity to orbital forcing through time (probably under different climatic regimes) or at different paleolatitudes.

The impoverishment of the benthonic foraminifera assemblages within the black shales, which were deposited under a low productivity regime, can be attributed to oxygen depletion under stratified water conditions. It coincides with predominance of the more specialized anaerobic forms within the infaunal assemblages, which are more sensitive indicators of oxygen content variations. In the more calcareous lithotypes, which were deposited under high productivity regimes, the impoverishment of the benthonic foraminiferal assemblages is interpreted as due to the rapid introduction of a large amount of sediment, mainly made up of nannoplankton, which tend to dilute the benthos.

On the basis of the distribution of species, genera, and morphogroups throughout the Amadeus Segment, aerobic, intermediate and anaerobic forms have been identified. In agreement with previous studies, the infaunal anaerobic forms have a high surface area to volume ratio. On the basis of our data, certain epifaunal forms are considered to be

\section{Explanation of Plate 2}

Fig. 1. Dentalinoides communis (d'Orbigny), sample AMS 2, x85. Fig. 2. Dentalinoides cylindroides (Reuss), sample AMS 2, x68. Fig. 3. Oolina sp., sample AMS 27, x51. Fig. 4. Oolina globosa (Montagu), sample AMS 16, x68. Fig. 5. Oolina apiculata Reuss, sample AMS 4, x68. Fig. 6. Oolina oxystoma (Reuss), sample AMS 16, x90. Fig. 7. Dentalinoides oligostegia (Reuss), sample AMS 6, x51. Fig. 8. Pleurostomella subnodosa Reuss, sample AMS 6, x51. Fig. 9. Pleurostomella sp., sample AMS 24, x51. Fig. 10. Gavelinella intermedia (Bethelin), sample AMS 8, x90. Fig. 11. Gavelinella flandrini Moullade, sample AMS8, x68. Fig. 12. Reussoolina sp., sample AMS 16, x68. Fig. 13. Eggerellina mariae Ten Dam, sample AMS 13, x51. Fig. 14. Arenobulimina ovoidea Marie, sample AMS 8, x51. Fig. 15. Dorothia pupa (Reuss), sample AMS 21, x68. Fig. 16. Dorothia glabrella Cushman, sample AMS 11, x68. Fig. 17. Marssonella oxycona (Reuss), sample AMS 4, x68. Fig. 18. Ammodiscus cretaceus (Reuss), sample AMS 4, x68. Fig. 19. Rhabdammina ex gr. discreta Brady, sample AMS 20, x90. Fig. 20. Dorothia sp., sample AMS 8, x51. Fig. 21. Dorothia gradata Berthelin, sample AMS 13, x34. Fig. 22. Clavulinoides gaultinus (Morozova), sample AMS 13, x68. 


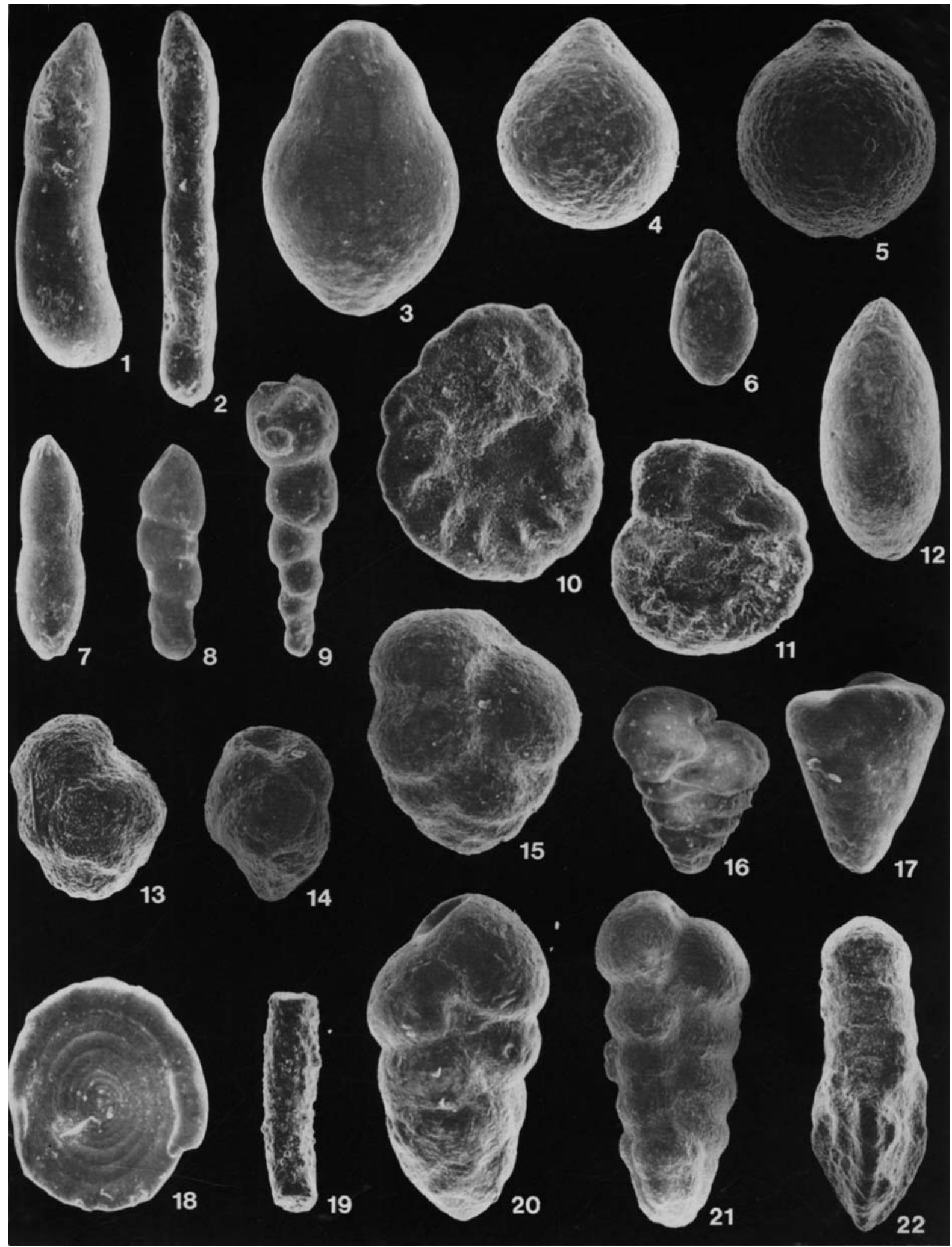


aerobic or intermediate indices. It must be pointed out that, for the same forms, other authors have proposed a different specialization with respect to the oxygen content. The cause of this different behaviour of the epifaunal assemblages can be attributed to the different paleoceanographic regime (that is very high productivity vs low productivity) under which the Amadeus Segment black shales were deposited.

\section{ACKNOWLEDGEMENTS}

We are grateful to M. A. Kaminski and J.R. Young for their critical and helpful reviews. Thanks are due to P. Ferrieri for assistance in operating the S.E.M. This paper has been supported by the M.U.R.S.T. $60 \%$ (R. Coccioni) and $40 \%$ (S. Raffi).

Species list arranged in taxonomic order following Loeblich \& Tappan (1988)

Rhabdammina ex gr. discreta Brady, 1881

Ammodiscus cretaceus (Reuss), 1862

Eggerellina mariae Ten Dam, 1950

Arenobulimina ovoidea Marie, 1941

Dorothia glabrella Cushman, 1933

Dorothia gradata Berthelin, 1880

Dorothia pupa (Reuss), 1860

Dorothia sp.

Marssonella oxycona Reuss, 1860

Clavulinoides gaultinus (Morozova), 1948

Dentalinoides communis (d'Orbigny), 1839

Dentalinoides cylindroides (Reuss), 1860

Dentalinoides oligostegia (Reuss), 1846

Nodosaria humilis Roemer, 1841

Nodosaria limbata d'Orbigny, 1840

Nodosaria sp. 1

Nodosaria sp. 2

Nodosaria sp. 3

Pseudonodosaria sp.

Pyramidulina obscura (Reuss), 1845

Pyramidulina paupercola (Reuss), 1846

Tristix excavata (Reuss), 1863

Lenticulina cf. acuta (Reuss), 1860

Lenticulina gaultina (Berthelin), 1880

Lenticulina ovalis (Reuss), 1844

Lenticulina sp.

Saracenaria bullata Reuss, 1846

Saracenaria sp.

Astacolus polandensis Trujillo, 1960

Planularia complanata (Reuss), 1845

Vaginulina kochii Roemer, 1841

Vaginulina sp.

Reussoolina sp.

Oolina apiculata (Reuss), 1851

Oolina globosa (Montagu), 1803

Oolina oxystoma (Reuss), 1863

Oolina sp.

Pleurostomella subnodosa Reuss, 1860

Pleurostomella sp.

Gyroidinoides nitidus (Reuss), 1846

Gavelinella flandrini Moullade, 1860

Gavelinella intermedia (Berthelin), 1880

\section{Manuscript received September 1992 \\ Manuscript accepted July 1993}

\section{REFERENCES}

Baccelle, L. \& Bosellini, A. 1965. Diagrammi per la stima visiva della composizione percentuale nelle rocce sedimentarie Annali Univ. Ferrara, ser. IX, 1(3), 59-62.

Bartolini, A., Nocchi, M., Baldanza, A. \& Parisi, G. in press. Benthic life during the early Toarcian anoxic event in the Southwestern Tethyan Umbrian basin (Central Italy). Fourth International Symposium on Benthic Foraminifera, Sendai, Japan, 28 Sept.-2 Oct. 1990.

Bernhard, J.M. 1986. Characteristic assemblages and morphologies of benthic foraminifera from anoxic, organicrich deposits: Jurassic through Holocene. J. Foramin. Res., 16 (3), 207-215.

Coccioni, R. 1990a. Benthonic foraminifera from the AptianAlbian organic-rich Scisti a Fucoidi of the Poggio le GuaineFiume Bosso composite sequence (Umbria-Marche Apennines, Italy). Pelagic and Flysch Facies Meeting (IGCP Project N. 262 "Tethyan Cretaceous Correlation"), Krakow, May 28-June 2, 1990, 18-19 (abstract).

Coccioni, R. 1990b. Morphologic and test size changes in the deep-water benthic foraminifera from the Aptian-Albian organic-rich Scisti a Fucoidi (Umbria-Marche Apennines, Italy). Fourth International Symposium on Benthic Foraminifera, Sendai, Japan, 28 Sept.-2 Oct. 1990, 33 (abstract).

Coccioni, R. \& Galeotti, S. 1991. Orbitally induced cycles in benthonic foraminiferal assemblages distribution from the Aptian-Albian organic-rich Scisti a Fucoidi (Central Italy). Pelagic and Flysch Facies 3rd Meeting (IGCP Project N. 262 "Tethyan Cretaceous Correlation"), Grenoble, May 26, 1991, 1-2 (abstract).

Coccioni, R., De Poli, A., Erba, E., Lottaroli, F. \& Premoli Silva, I 1990a. Lithostratigraphy and biostratigraphy of the AptianAlbian Scisti a Fucoidi Formation (central Italy): evidence for hiatuses and their paleotectonic and paleoenviromental implications. $3^{\circ}$ Convegno Internazionale "Fossili, Evoluzione, Ambiente", Pergola, 21-28 ottobre 1990, 41 (abstract).

Coccioni, R., Franchi, R., Nesci, O., Perilli, N., Wezel, F.C. \& Battistini, F. 1990b. Stratigrafia, micropaleontologia e mineralogia delle Marne a Fucoidi delle sezioni di Poggio le Guaine e del Fiume Bosso (Appennino umbro-marchigiano). Atti $2^{\circ}$ Convegno Internazionale "Fossili, Evoluzione, Ambiente", Pergola, 25-30 ottobre 1987. Tecnostampa, 163-201.

Coccioni, R., Franchi, R., Nesci, O., Wezel, F.C., Battistini, F. \& Pallecchi, P. 1989. Stratigraphy and mineralogy of the Selli Level (Early Aptian) at the base of the Marne a Fucoidi in the Umbro-Marchean Apennines, Italy. In Wiedmann, J. (Ed.), Cretaceous of the Western Tethys. Proceedings 3rd International Cretaceous Symposium, Tubingen 1987, E. Schweizerbart Verlagsbuchhandlung, Stuttgart 563-584.

Coccioni, R., Nesci, O., Tramontana, M., Wezel, F.C. \& Moretti, E. 1987. Descrizione di un livello-guida "radiolariticobituminoso-ittiolitico' alla base delle Marne a Fucoidi nell'Appennino umbro-marchigiano. Boll. Soc. Geol. It., 106(1), 183-192.

Corliss, B.H. \& Chen, C. 1988. Morphotype patterns of Norwegian Sea deep-sea benthic foraminifera and ecological implications. Geology, 16, 716-719. 
Cottle, R.A. 1989. Orbitally mediated cycles from the Turonian of southern England: their potential for high-resolution stratigraphy correlation. Terra nova, 1 (5), 426-431.

de Boer P.L. 1982. Cyclicity and storage of organic matter in middle Cretaceous pelagic sediments. In Einsele G. \& Seilacher A. (Eds.), Cyclic and Event Stratification, SpringerVerlag, 456-474.

de Boer P.L. \& Wonders A.A.H. 1984. Astronomically induced rhythmic bedding in Cretaceous pelagic sediments near Moria (Italy). In Berger A.L. et al. (Eds.), Milankovitch and Climate, Riedel Publ. Company, 117-190.

Erba, E. 1988. Aptian-Albian calcareous nannofossil biostratigraphy of the Scisti a Fucoidi cored at Piobbico (central Italy). Riv. It. Paleont. Strat., 94(2), 249-284.

Erba, E. 1992. Calcareous nannofossils distribution in pelagic rhytmic sediment (Aptian-Albian Piobbico Core, Central Italy). Riv. It. Paleont. Strat., 97 (3-4), 455-484.

Fischer A.G. \& Herbert T.D. 1988. Stratification rhythms: Italoamerican studies in the Umbrian facies. Mem. Soc. Geol. It., 31, 45-51.

Fischer A.G. \& Schwarzacher W. 1984. Cretaceous bedding rhythms under orbital control? In Berger A.L. et al. (Eds.), Milankovitch and Climate, Riedel Publ. Company, 165-175.

Fischer A.G., Herbert T.D., Napoleone G., Premoli Silva I. \& Ripepe M. 1991. Albian pelagic rhythms (Piobbico core). I. Sedim. Petrol., 61, 1164-1172.

Fischer A.G., Herbert T.D \& Premoli Silva I. 1985. Carbonate bedding cycles in Cretaceous pelagic and hemipelagic sequences. In Pratt L.M. et al. (Eds.), Fine-grained deposits and biofacies of the Cretaceous Western Interior Seaway: evidence of cyclic sedimentary processes. Soc. Econ. Paleont. Min. Field Trip Guidebook, 4, 1-10.

Herbert T.D. 1987. Eccentricity and Processional Orbital Periodicities in a mid-Cretaceous deep-sea sequence: identification and application to quantitative paleoclimatology. Ph.D. Thesis, Univ. Princeton, $250 \mathrm{pp}$

Herbert T.D., Stallard R.F. \& Fischer A.G. 1986. Anoxic events, productivity rhythms and the orbital signature in a midCretaceous deep-sea sequence from central Italy. Paleoceanography, 1, 495-506.

Herbert T.D. 1992. Paleomagnetic calibration of Milankovitch cyclicity in Lower Cretaceous sediments. Earth Planet. Sci. Lett., 112, 15-28.

Herbert T.D. \& Fischer A.G. 1986. Milankovitch climatic origin of mid-Cretaceous black shales rhythms in Central Italy. Nature, 321, 739-743.

Herguera J.C. \& Berger W.H. 1991. Paleoproductivity from benthic foraminifera abundance: Glacial to postglacial change in the west-equatorial Pacific. Geology, 19(12), 1173-1176.
Jones, R.W. \& Charnock, M.A. 1985. "Morphogroups" of agglutinating foraminifera. Their life positions and feeding habits and potential applicability in (paleo)ecological study. Revue Paléobiol., 4(2), 311-320.

Kaiho, K. 1991. Global changes of Paleogene aerobic-anaerobic benthic foraminifera and deep-sea circulation. Palaeogeogr., Palaeoclimatol., Palaeoecol., 83, 65-85.

Koutsoukos, E.A.M. \& Hart, M. B. 1990. Cretaceous foraminiferal morphogroup distribution patterns, palaeocommunities and trophic structures: a case study from the Sergipe Basin, Brazil. Trans. R. Soc. Edinb.: Earth Sciences, 81, 221-246.

Leary, P.N., Cottle, R. \& Ditchfield, P.W. 1989. Milankovitch control of foraminiferal assemblages from the Cenomanian of southern England. Terra nova, 1, 416, 419.

Leutenegger, S. \& Hansen, H.J. 1979. Ultrastructural and radiotracer studies on pore function in foraminifera. Mar. Biol., 54, 11-16.

Loeblich, A.R. Jr \& Tappan, J.H. 1988. Foraminiferal Genera and their classification. Van Nostrand Reinhold Company, New York, 1 and 2, 1-970 and 1-212.

Premoli Silva, I. \& Erba, E. 1991. Orbitally driven cycles in trace fossil distribution from the Piobbico core, Late Albian, central Italy. Terra abstracts, 3 (1), 289.

Premoli Silva, I., Erba, E. \& Tornaghi, M.E. 1989a. Paleoenvironmental signals and changes in surface fertility in mid-Cretaceous Corg-rich pelagic facies on the Fucoid Marls (central Italy). Geobios, mem. spéc., 11, 225-236.

Premoli Silva, I., Erba, E. \& Tornaghi, M.E. 1989b. Mid Cretaceous Corg-rich pelagic facies: their climatic significance and relationship with changes in primary productivity. In Boriani et al. (Eds.), The Lithosphere in ItalyAdvances in Earth Science Research, Rome, 5-6 May 1987, Accad. Naz. Lincei, Atti Conc. Lincei, 80, 325-340.

Premoli Silva, I., Ripepe, M. \& Tornaghi, M.E. 1989c. Planktonic foraminiferal distribution record productivity cycles: evidence from the Aptian-Albian Piobbico core (central Italy). Terra nova, 1 (5), 443-448.

Ripepe, M., 1988. Stratabase: a stratigraphical database and processing program for microcomputers. Compuler Geoscience, 14, p. 369-375.

Schwarzacher W. \& Fischer A.G. 1982. Limestone-shale bedding and perturbations in the Earth's orbit. $1 n$ Einsele G. \& Seilacher A. (Eds.), Cyclic and Event Stratification, Springer-Verlag, 72-95. 